\title{
AZ ÉLELMISZER VÁLASZTÁSRA HATÓ TÉNYEZŐK FELTÁRÁSA
}

\author{
Fodor Fanni Ildikó - Naárné Tóth Zsuzsanna
}

\section{Összefoglalás}

Az élelmiszerek bozzájárulnak a létfenntartásunkhoz, jelen vannak mindennapjainkban. Átszövik a bétköznapokat, az ünnepeket és a különböző́ jeles eseményeket. Ételeket fogyasztunk örömszeržés céljából, jutalmazás céljából, azonban általuk kifejęhetjük a személyiségünk is.

A XXI. században számos új élelmiszerfogyasztási trend jelent meg. Napjainkban a közösségi média által rengeteg információho juthatunk számos élelmiszer trendekhez kapcsolódóan, melyek. befolyásolják élelmiszuer választási preferenciáinkat.

Jelen szakirodalmi összefoglalónkban elsödleges célunk, hogy bemutassuk az élelmiszerek vásárlásai során a

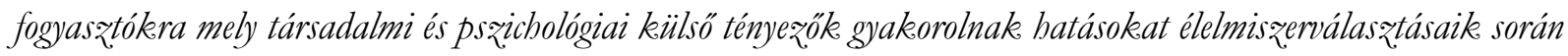
szekeunder adatgyüjtés segitségével, hazai és nemzetkö̈zi szakirodalmak felhasználásával.

Feltárjuk a Vebleni hivalkodó fogyaszৃtás mögöttes pszichológiai okait és kitérünk az élelmiszerekekel kapcsolatos érzelmek elemzésére, az élelmiszer márkákhoz való fogyaszutói kötödésre, a márka szeretet jellemzésére is egyaránt.

Kulcsszavak: élelmiszer-fogyasztás, fogyasztói magatartás, társadalmi tényezőke, pszichológiai tényezőo, márka JEL: M31 


\title{
EXPLORATION OF FACTORS AFFECTING FOOD CHOICE
}

\begin{abstract}
Food contributes to our livelihoods and is present in our daily lives. They weave through everyday life, holidays and various notable events. We consume food for pleasure, for reward, but they can also express our personality.

In the twentieth century, many new food consumption trends emerged. Nowadays, social media provides a wealth of information related to a number of food trends that affect our food choice preferences.

In our literature review, our primary goal is to present which social and psychological external factors have an impact on consumers when purchasing food through secondary data collection using hungarian and international literature.

We explore the underlying psychological causes of Vebleni's ostentatious consumption and analyze the emotions related to food, the consumer's attachment to food brands, and the characterization of brand love.
\end{abstract}

Keywords: food consumption, consumer behavior, social factors, psychological factors, brand JEL: M31 


\section{Bevezetés}

Az élelmiszer-fogyasztás a fogyasztói magatartás egyik meghatározó területe, hiszen az étkezés hozzájárul létfenntartásunkhoz és része mindennapjainknak.

Az élelmiszerek sokfélesége biztosítja az emberiség számára a tápanyagszükségletet és a kiegyensúlyozott táplálkozást.

Napjainkban az élelmiszerekkel kapcsolatos fogyasztói magatartásvizsgálatok nagy népszerúségnek örvendenek. Ezt alátámasztja, hogy a fogyasztói magatartáskutatásban paradigmaváltás következett be, miszerint a fogyasztók megismeréséhez már nem elegendőek a különböző demográfiai ismérvek feltárása és azonosítása. Mára a fogyasztók magatartása mögött rejlő attitűdök, értékek megismerése áll a fogyasztói magatartás vizsgálatok fókuszában. (Berke, 2003)

Az ételek fogyasztása során az alapvető biológiai szükségletkielégítés mellett az étel megjelenése, íze és illata élvezeti forrást nyújt.

Az emberiség kialakulásától kezdve az étkezés mindennapjainkat átszövi, eszköze a közösség formálásnak és összetartozás segít elő ezáltal az ételekhez fűződő érzelmek több aspektusból vizsgálhatók. (Stearns- Stearns, 1985)

\section{Anyag és módszer}

Publikációnk elsődleges célja, hogy bemutassuk az élelmiszer-fogyasztásra ható társadalmi, - szociológiai és pszichológiai tényezôk hogyan mutatkoznak meg az élelmiszer-fogyasztási preferenciákban napjainkban.

Hazai és nemzetközi szakirodalmak felhasználásával szekunder vizsgálatot végeztünk, melyben áttekintettük az élelmiszer-fogyasztói magatartási modelleket és az élelmiszer-választást meghatározó társadalmi- és pszichológiai tényezőket, feltártuk a fogyasztók hivalkodó fogyasztásának mögöttes okait és az élelmiszer márkákhoz való kötődés pszichológiai háttér tényezőit egyaránt.

\section{Élelmiszer-fogyasztási modellek}

Az élelmiszer-fogyasztói magatartással kapcsolatos kutatások során számos modell született. Pilgrim (1957) magatartási modellje (1. ábra) szerint az élelmiszer-elfogadás és -választás alapvető meghatározója az észlelés, mely az élelmiszer tulajdonságai és az azokra épülő fiziológiai hatások, valamint érzékszervi tulajdonságok, érzékszervi észlelés és a környezeti tényezők hatásai. A modell az időtényezôt közvetett módon tartalmazza, a környezeti tényezők hosszú távra vonatkozó hatásával és a szükségletek rövid távú hatásával egyaránt. Az élelmiszer-választás alapvetô meghatározója az észlelés, mely az élelmiszer tulajdonságai és az azokra épülő fiziológiai hatások, valamint érzékszervi tulajdonságok, érzékszervi észlelés és a környezeti tényezők hatásai. E modell szemlélteti, hogy a fogyasztói döntést pszichológiai tényezők is befolyásolják. 
Fodor F. I. - Naárné T. Zs. É.

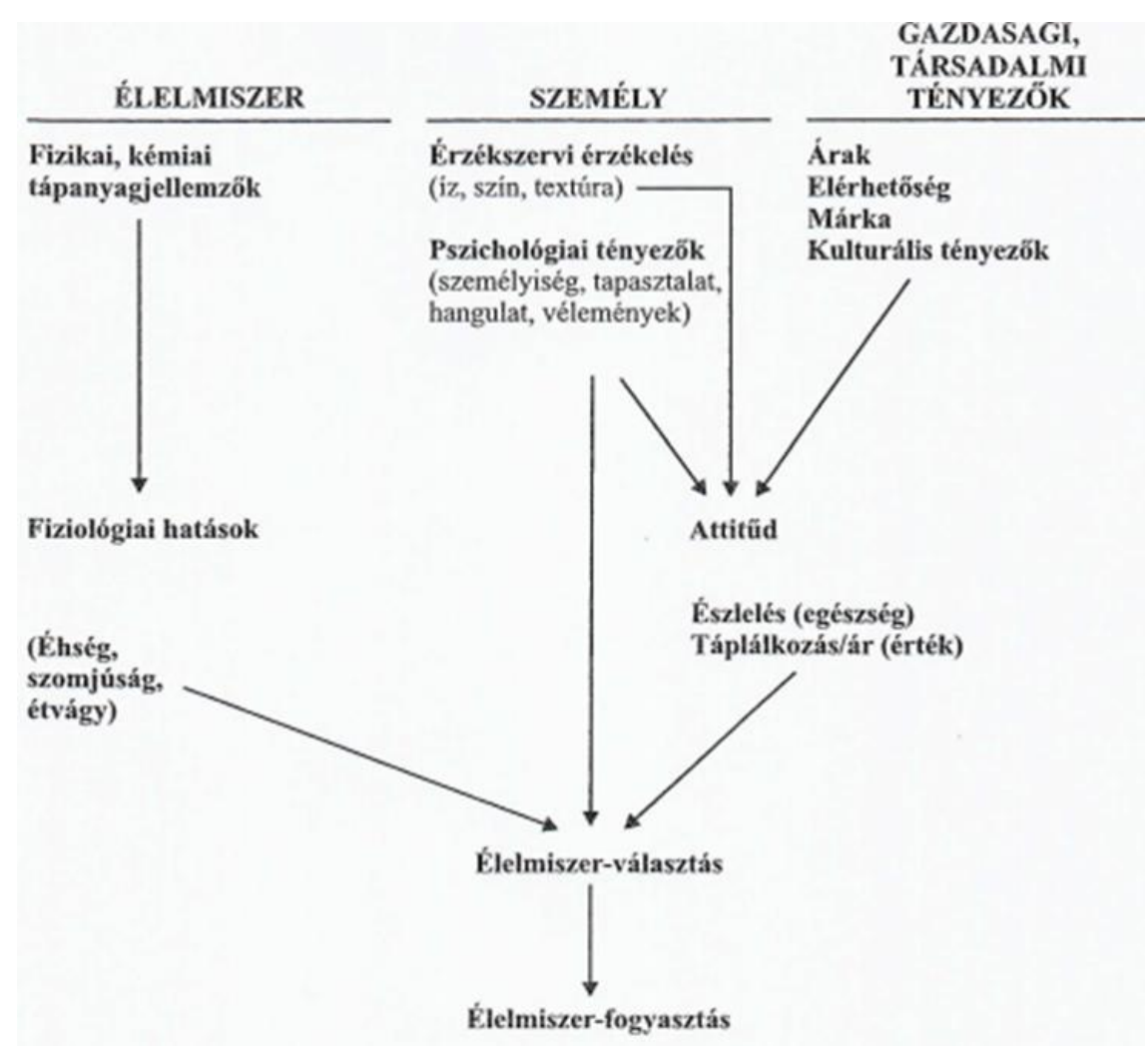

1. ábra Pilgrim-féle élelmiszer-fogyasztói magatartás modell

Forrás: Lehota, 2001

A Pilgrim modell továbbfejlesztése kapcsán született meg a Stepherd-féle élelmiszer-fogyasztói, -vásárlói magatartási modell. A vásárlói és döntési folyamatra helyezi a hangsúlyt és arra vonatkoztatja a többi tényező hatását is (2. ábra). Az élelmiszer-tulajdonságok a fiziológiai tulajdonságok és érzékszervi hatásokon keresztül befolyásolják a vásárlói magatartást, egyéni tényezők lehetnek: kor, nem, testsúly, táplálkozás és a környezeti tényezők lehetnek: ár, márka vagy az értékesítési csatorna.

Élelmiszer

Fizikai, kémiai és tápanyag jellemzók

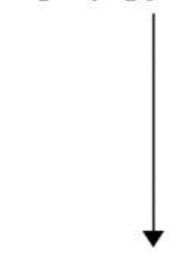

Fiziológiai hatások pl. jóllakottság, éhség, szomjúság, étvágy
Személy

Érzékszervi érzékelés pl. megjelenés, aroma, íz, textúra

Pszichológiai tényezôk pl. személyiség, tapasztalat, hangulat, hitek

\section{Gazdasági,} társadalmi tényezók 
A Steenkamp (1997) modelljében (3. ábra) már a döntési folyamatokat helyezi előtérbe, melyekre befolyással bírnak az élelmiszer-tulajdonságok, biológiai és pszichológiai szükségletek, valamint a társadalmi-demográfiai hovatartozás is egyaránt (Szakály, 2017).

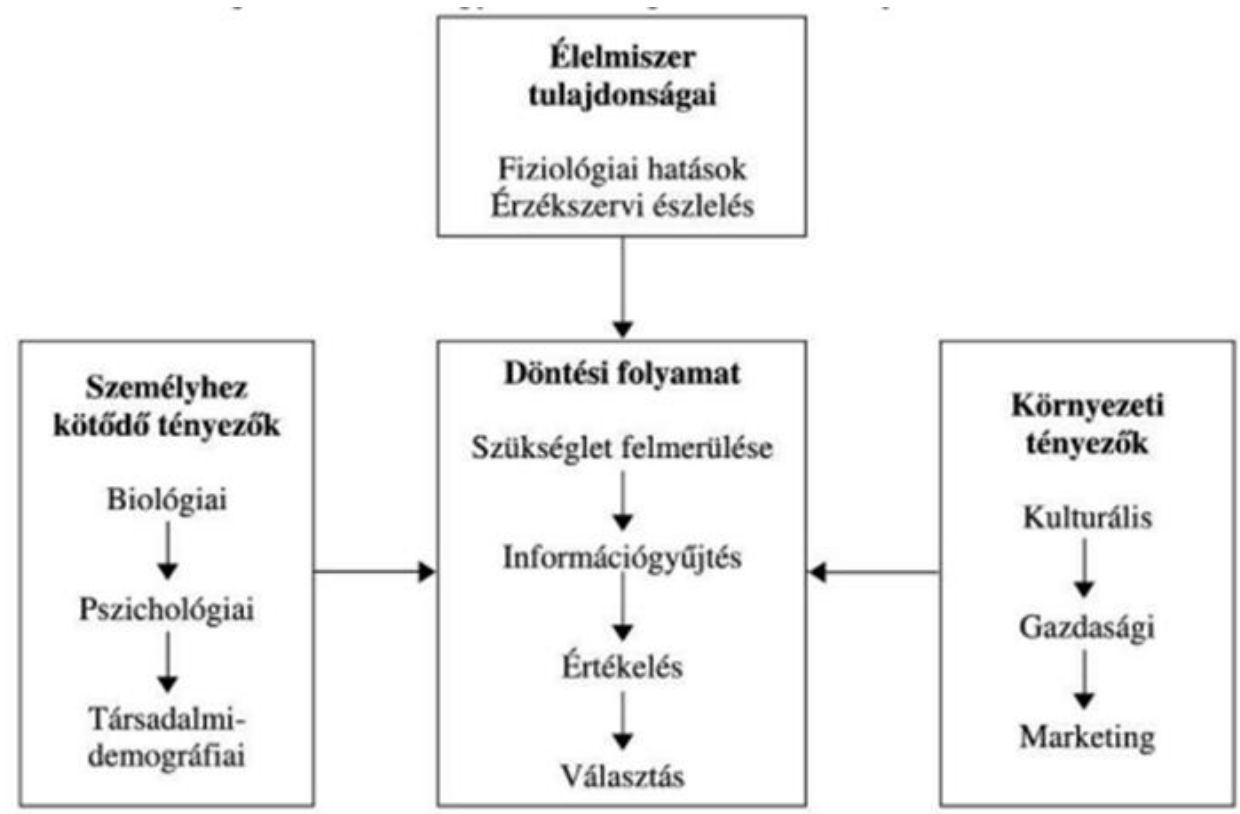

\section{3. ábra Steenkamp élelmiszerfogyasztói magatartás modellje}

Forrás: Steenkamp (1997)

\section{Fogyasztók táplálkozását meghatározó tényezők}

A társadalmi tényezők közül az interperszonális kapcsolatok jelentősen befolyásolják az ételválasztást (Blake et al.,2009; Chen és Kwan, 2015).

Kotler (2002) szerint a fogyasztók döntéseit meghatározzák a személyes interakciók. Döntésük során a legnagyobb befolyásoló erővel a személyes források rendelkeznek.

Kiemelkedő szereppel bírnak a családtagok, barátok és ismerősök melyek, mint referenciacsoportok jelennek meg. Ezek közül kiemelkedő szerepe van a családnak, mint legnagyobb befolyással bíró referenciacsoport, mert az egyének születésüktől fogva a szülói nevelés hatására alakítják ki saját értékrendjüket, melyek tükröződnek táplálkozási szokásaikban egyaránt. Kiss és Szakály (2016) kutatásuk során megállapították, hogy erős összefüggés áll fenn a szülők és gyermekeik táplálkozási attitűdjeik között, azonban az anyák szerepe dominánsabb az apák életmód formálásánál. A személyes interakciók mellett információkhoz jutnak az online marketing által közvetített élelmiszerfogyasztást befolyásoló hatásokról (McKinley et al., 2005).

Az élelmiszer-fogyasztást számos személyes jellemző is befolyásolja, mint az életkor, foglalkozás, életmód, gazdasági körülmény, személyiség, énkép. Pszichológiai tényezők közül a motiváció, mint szükséglet erőteljes cselekvésre késztet és a szükséglet kielégítése feszültség csökkentést eredményez. Az érzékelés függ a személyiségtől és az inger környezetétől, azonban a motivált egyént cselekvésre ösztönzi. A fogyasztók cselekvések közben tanulnak, így a tanult emberi magatartásforma által saját attitűdöket és hiteket képesek kialakítani magukban, melyek hatással lesznek vásárlási magatartásaikra (Kotler, 2002). 
Az egyén fogyasztását tükrözi a társadalmi rétegződésben elfoglalt helye. Az élelmiszerek fogyasztása során státuszt jelenít meg és az étel, mint egyfajta státuszszimbólumként jelenik meg, mely által kifejeződik a tényleges vagy a vágyott társadalmi csoporthoz való tartozásuk (HofmeisterTóth, 2014).

Társadalmi azonosság kifejezésére szolgál, hogy valaki milyen módon, kivel és mit eszik., ezáltal megmutatkozik a társadalmi csoporthoz való hovatartozása (Forgács, 2018). Veblen (1899) szerint a magasabb anyagi jövedelemmel rendelkező fogyasztók hivalkodó fogyasztásukkal hívják fel magukra a figyelmet és kísérlik meg vagyoni helyzetüket demonstrálni. A hivalkodó fogyasztás mögött két motiváció húzódik meg. Az egyik motiváció az irigylésre méltó összehasonlítás, mely során az egyén magatartásában hivalkodva megkülönbözteti magát az alacsonyabb osztálybeli egyénektől. A másik motiváció az anyagi versengés, mely során az alacsonyabb társadalmi osztályba tartozók vágyódnak és törekednek a felsôbb osztályba tartozásra hivalkodó fogyasztásukkal (Bagwell és Bemheim, 1996). Campbell szerint a Vebleni hivalkodó fogyasztás elmélete három komponensből épül fel. Az első komponensben a hivalkodó fogyasztás egyfajta motivációként jelenik meg, ahol a fogyasztó anyagi helyzetét tudatosan prezentálja olyan termékek vásárlásával, amelyekkel kifejezheti státuszát. A második komponens szerint a hivalkodó fogyasztás, mint követelmény jelenik meg. Cél, hogy olyan benyomást keltsen másokban, hogy képes megfizetni az adott hivalkodó terméket. A harmadik komponens szerint a hivalkodó fogyasztás a fogyasztó magatartásának egy belső minősége, mely összefügg a pazarlással (Tilman, 2006).

\section{Élelmiszermárkákhoz való kötődés}

Törőcsik (2000) szerint a szimbolikus fogyasztás olyan termékek fogyasztását jelenti, amelyek szükségessége nehezen magyarázható és nem következik a fogyasztó korábbi fogyasztói magatartásából, másrészt olyan márkák vásárlása, melyek üzeneteivel az egyén azonosulni tud és fogyasztás által kifejezhető egyfajta érzelmi többlet.

A szimbolikus fogyasztás esetében a termékekkel kapcsolatos érzelmek dominálnak. A fogyasztók nemcsak a funkcionális hasznokért vásárolnak termékeket, hanem a termékekhez kapcsolódó jelentéstartalmuk miatt egyaránt (Levy, 1959). A szimbolikus fogyasztás mögött kettős motiváció áll. Önmegnyugtató fogyasztás, mikor szubjektív egyéni vélemény és attitűd számít a termékkel szemben. A fogyasztás célja egyfajta jutalmazás, önmegnyugtatás, örömszerzés. Az önkifejező fogyasztás esetében pedig a környezettől várja a cselekvéséről való visszaigazolást, törekedve a pozitív benyomás elérésére másoktól (Törőcsik, 2016).

A márkaszimbolizmushoz való kötődés összefügg a márka által sugall pozitív képpel és a márka által képviselt személyiségjegyekkel (Kressman et al., 2006; Gyulavári és Malota, 2014). Sirgy (1982) véleménye szerint fogyasztói döntéskor énkép-illeszkedés valósul meg, mert a márka imázsa attól függ, hogy mennyire illeszkedik a fogyasztó énképéhez.

Számos kutatás született a fogyasztó és márka közötti viszony elemzésére multidiszciplináris területen, azonban e három fő irányzat terjedt el; fogyasztó-márka viszonyának területe, amikor a szükségletkielégítés mellett egyben önkiteljesítési folyamatok is megvalósulnak (Wattanasuwan, 2005). A márkaillesztés kutatások során a márkák személyisége és a fogyasztó énképe közötti kapcsolatokat vizsgálják és a márkakötődés kutatások során a kötődés alapja a folyamatos interakció, amikor a vizsgálat alapja a fogyasztó és a kutatások középpontjában a márkához való miként kötődés áll (Albert és Merunka, 2013). 
A fogyasztók erős érzelmi kötődése a márkákhoz megmutatkozik az élelmiszermárkák esetében is egyaránt.

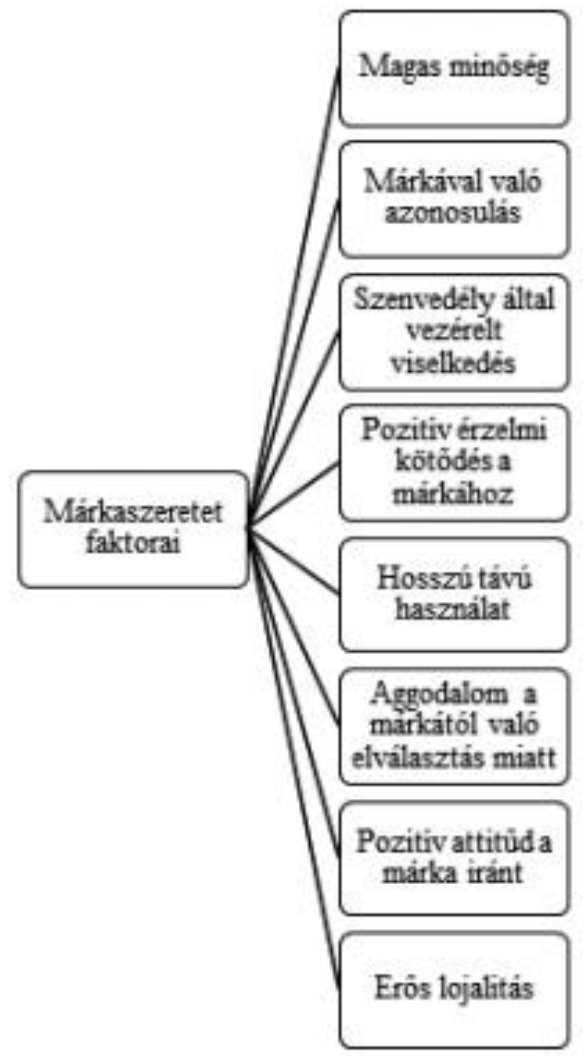

4. ábra Márkaszeretet tényezői

Forrás: Batra et al., 2012 in Tamasits és Prónay (2016)

Batra et al. (2012) kutatásukban megállapították, hogy a márkák szeretete több tényező komplex hatására alakul ki. Az alábbi nyolc tényezôt azonosították, melyek közrejátszanak a márka szeretetének kialakulásában, melyet a 4. ábra szemléltet. A magas minőség, a márkával való azonosulás, a szenvedély által vezérelt viselkedés, a fogyasztók pozitív érzelmi kötődése a márkához, a hosszú távú kapcsolat, aggodalom a márkától való elválasztás miatt, az attitűd iránya és erôssége, valamint a lojalitás erőssége. Lockie et al. (2002) tanulmányukban azt vetik fel, hogy az élelmiszerekben rejlő természetes tartalom az egyik legerősebb fogyasztást befolyásoló tényező és a magasabb természetes tartalom, magasabb minőségi megítéléssel rendelkezik, ezáltal márkaelköteleződést eredményez. Az élelmiszerek márkaimázsa pszichológiai élményt nyújt a fogyasztók számára és márkaszeretetre ösztönző erôt vált ki (Steenkamp és Batra, 2003). A fogyasztók azonosulnak a márkával, ezért a márkás élelmiszerek megvásárlásával hajlandóak elfogadni, hogy magas árat kell érte fizetni, melynek fogyasztása tükrözi a társadalmi státuszukat (Alden et al., 1999).

\section{Köveztetések}

A fogyasztók élelmiszer vásárlásaik során számtalan befolyásoló tényezővel érintkeznek. Szakirodalmi összefoglalónkban a teljesség igénye nélkül a társadalmi és pszichológiai tényezők elemzésére fókuszáltunk. Az élelmiszer-fogyasztás során a fogyasztók alapvető szükségletkielégítésük mellett demonstrálják a társadalomban betöltött szerepüket vagy a vágyott csoporthoz való tartozásukat. 
Az élelmiszer-fogyasztás eszközként szolgál, mellyel kifejező a státusz. A vebleni hivalkodó fogyasztás jelen van az élelmiszerek vásárlása esetében is, hiszen az egyének társadalmi előnyökre szeretnének szert tenni ezek által.

Az élelmiszer-fogyasztás során az élelmiszerek márkáival való azonosulás következtében erôs kötődés alakul ki. Ennek következtében egyrészt a fogyasztói énképpel való azonosulás valósul meg, másrészt a társadalom számára jelzô, társadalmi rétegben elfoglalt hely mutatkozik meg.

Az élelmiszermárkákhoz való érzelmi kötődés hosszú távú kapcsolatot igényel a fogyasztó és a márka között. A márkaszeretet esetében a márka személyiségjegyei illeszkednek a fogyasztó személyiségéhez, ezáltal megvalósul a márkához való kötődés.

\section{Köszönetnyilvánítás}

„Az Innovációs és Technológiai Minisztérium ÚNKP-20-3-II. kódszámú Új Nemzeti Kiválóság Programjának a Nemzeti Kutatási, Fejlesztési és Innovációs Alapból finanszírozott szakmai támogatásával készült.”

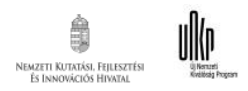

\section{Hivatkozott források}

[1.] Albert N. - Merunka D. (2013): The role of brand love in consumer-brand relationships. Journal of Consumer Marketing. 30 (3), 258-266.

[2.] Alden D. L. - Steenkamp J.B.E.M. - Batra R. (1999): Brand positioning through advertising in Asia, North America, and Europe: the role of global consumer culture. Journal of Marketing. 63 (1), 75-87.

[3.] Bagwell L. S. - Bernheim B. D. (1996): Veblen Effects in a Theory of Conspicuous Consumption. American Economic Review. 86 (3), 349-373.

[4.] Batra R. - Ahuvia A. - Bagozzi P. R. (2012): Brand Love. Journal of Marketing Research. 76, 116.

[5.] Berke Sz. (2003): A funkcionális minőség összetevőinek fogyasztói megítélése állati eredetű alapélelmiszereknél. PhD értekęés. Kaposvári Egyetem. Kaposvár. 200

[6.] Blake C. E. - Wethington E. - Farrell T. J. -Bisogni C. A. - Devine C. M. (2009): Behavioral contexts, food-choice coping strategies, and dietary quality of a multiethnic sample of employed parents J. Am. Diet Assoc., 111 (3) 401-407.

[7.] Chen X. - Kwan M. P. (2015): Contextual uncertainties, human mobility, and perceived food environment: the uncertain geographic context problem in food access research American. Journal. Publ. Health. 105 (9) 1734-1737.

[8.] Forgács A (2018): Az evés lélektana, Akadémiai Kiadó, Budapest

[9.] Gyulavári T. - Malota E. (2014): Az énkép-illeszkedés elmélet szerepe a fogyasztók turisztikai desztinációértékelésében. Marketing \& Management. 48 (3), 5-14.

[10.] Hofmeister-Tóth Á. (2014): A fogyasztói magatartás alapjai, Akadémiai Kiadó, Budapest

[11.] Kiss V. - Szakály Z. (2016): A szülők hatása a középiskolás diákok egészségtudatos táplálkozására, EMOK - XXII. Országos Konferencia- Hitelesség és értékorientáció a marketingben

[12.] Kotler P. (2002): Marketing menedzsment., Akadémiai Kiadó, Budapest 
[13.] Kressman F. - Sirgy M.J. - Herrmann A. - Huber F. - Huber S. - Lee D.J. (2006): Direct and indirect effects of self-image congruence on brand loyalty. Journal of Business Research. 59 (8), 955-964.

[14.] Lehota J. (2001): Agrármarketing, Marketingkutatás az agrárgazdaságban, Mezőggazđda Kiadó, Budapest

[15.] Levy S. J. (1959): Symbols for sale. Harvard Business Review. 37 (4), 117-124.

[16.] Lockie S. - Lyons K. - Lawrence G. - Grice, J. (2004): Choosing organics: a path analysis of factors underlying the selection of organic food among Australian consumers. Appetite 43, 135146.

[17.] McKinley M.C. - Lowis C. - Robson P.J. (2005): It's good to talk: Children's views on food and nutrition. American Journal of Clinical Nutrition 59, 542- 551.

[18.] Pilgrim F. J. (1957): The Components of Food Acceptance and their Measurement. American Journal of Clinical Nutrition 5 (2), 171-175.

[19.] Sirgy M. J. (1982): Self-concept in consumer behavior: A critical review. Journal of consumer research. 9, 287-301.

[20.] Stearns, C. Z. - Stearns P. N. (1985): Emotionology: Clarifying the History of Emotions and Emotional Standards. The Americal Historical Review. 90 (4), 813-836.

[21.] Steenkamp J. B. E. M. (1997): Dynamics in Consumer Behavior with Respect to Agricultural and Food Products. In Wierenga B. - van Tilburg A. - Grunert K. - Steenkamp, J. B. E. M. - Wedel M. (Eds.), Agricultural Marketing and Consumer Behavior in a Changing World. Springer US, Boston, 143-188.

[22.] Steenkamp J.B.E.M. - Batra R. (2003): How perceived brand globalness creates brand value, Journal of International Business Studies 34, 53-65.

[23.] Szakály Z. (2017): Élelmiszer-marketing, Akadémia Kiadó, Budapest

[24.] Tamasits D. - Prónay Sz. (2016): A fogyasztói márkakötődés mozgatórugói: A márkaszeretet koncepciója. EMOK XXII. Országos konferencia - Hitelesség és értékorientáció a marketingben, 472 .

[25.] Tilman R. (2006): Colin Campbell on Thorstein Veblen on Conspicuous Consumption. Journal of Economic Issues, 40 (1), 97-112.

[26.] Törőcsik M. (2000): Empatikus marketing. Bagolyvár Könyvkiadó, Budapest

[27.] Törőcsik M. (2016): Fogyasztói magatartás Insight, trendek, vásárlók, Akadémiai Kiadó, Budapest

[28.] Veblen T.B. (1899): The Theory of the Leisure Class, Houghton Mifflin, Boston

[29.] Wattanasuwan K. (2005): The self and symbolic consumption. The Journal of American Academy of Business. 3, 179-184. 
Fodor F. I. - Naárné T. Zs. É.

\section{Szerző(k)}

Fodor Fanni Ildikó

PhD hallgató

MATE GRTDI Doktori Iskola

fodorfanni@gmail.com

Naárné Tóth Zsuzsanna

egyetemi docens

MATE Gazdaságtudományi Intézet

naarne.toth.zsuzsanna.eva@uni-mate.hu 